\title{
Den museale forsknings fremtidsudsigter
}

\author{
Signe Margrethe Eberhardt Sørensen*
}

Title: The future of Danish art museum research.

Abstract: It is possible to trace an internal problem in the world of Danish art museums. Research institutions of this type are undecided concerning their definitions and terms of research.

This appears to be problematic, as this type of institution faces heavy political demands that seem to be almost impossible to satisfy on account of the specific type of research cnducted at an art museum. I therefore consider it absolutely necessary to explain the fundamental research definitions relevant to Danish art museums, in order to show the essence of what makes them different from the scientific research tradition currently on the agenda.

Key words: Museum research, Danish art museums, research measurement, relevance to society, use to society.

DEN DANSKE REGERINGS KRAV TIL FORSKNING

Skal den danske velfærdsstat overleve, bør der i fremtiden fokuseres på forskning, innovation og iværksætteri. Danmark skal være et førende vækst- og videnssamfund ${ }^{1}$. Så kort kan budskabet i rapporten "Aftale om fremtidens velstand og velfærd og investeringer i fremtiden" fra Finansministeriet formuleres. Ønsker man at få et indblik i, hvilken type forskning det er, Danmark så skal leve af $\mathrm{i}$ fremtiden, kan svaret bl.a. findes i rapporten "Samspil - nye veje mellem forskning og erhverv" fra Videnskabministeriet. Her understreges nødvendigheden af at fokusere på den anvendelsesorientere- de og samfundsrelevante forskning ${ }^{2}$ eller den forskningstype, hvis resultater $\mathrm{i}$ sidste ende kan måles i økonomisk vækst. Af samme årsag øges de offentlige forskningsbevillinger i disse år markant, så de fra og med 2010 vil udgøre $1 \%$ af Danmarks samlede bruttonationalprodukt. $^{3}$

Forskningsmidlerne vil bl.a. blive afsat som basisbevillinger til opbygning af såvel universitære som museale forskningsmiljøer inden for basisforskningen. For at bevillige de mange forskningsmidler til de forskningsprojekter, der sætter samfundsrelevans og anvendelsesorientering i højsædet, udviklede Danmarks Forskningspolitiske Råd, i juni 2006 et værktøj til måling af forskningens kvalitet og relevans. ${ }^{4} \mathrm{I}$ 
denne publicering kategoriseres hvor godt et forskningsområde er ved hjælp af fire kvalitetsindikatorer eller kvalitetskriterier:

- Publicering. Antal peer review publikationer pr. VIP- forskningsværk pr. år som et gennemsnit over de seneste tre år. Publikationshyppighed sviger fra område til område og derfor sættes publikationshyppighed i perspektiv overfor niveauet for sammenlignelige nationale og internationale forskningsområder. Vurderingen baseres på mængde og impact factor.

- Citationer. Citationer specificeret i forhold til en tidsperiode: Gennemsnitlige antal citationer pr. publikation pr. år i relation til sammenlignelige nationale og internationale forskningsområder inden for de seneste fem år.

- Eksterne forskningsbevillinger/-indtægter. Omfanget af eksterne forskningsmidler tildelt af nationale og internationale private og offentlige fonde og forsk- ningsråd på grundlag af konkurrence og kvalitetsbedømmelse opgjort over en femårig periode samt andre indtægter som følge af forskning, f.eks. royalties.

- Formaliseret internationalt forskningsarbejde. Samarbejde omfattende publicerings-fællesskab og fælles forskningsbevillinger. ${ }^{5}$

Forskningens relevans kategoriseres i skriftet som det samlede niveau for forskningens betydning for det omgivende samfund og beskrives ved hjælp af følgende to indikatorer:

- Relevans for erhverv. Omfanget af samarbejde med private virksomheder indenfor de seneste år, hvor relevante mål for erhvervsmæssig betydning er patenter, kommerciel susses, erhvervsPhDer, formaliserede samarebjder, spin offs, m.m.

- Relevans for øvrige samfund. Beskrivelse af samfundsmæssig betydning, herunder kernefeltets bidrag til uddannelse af kandidater og ph.der, indførelse af ny patentbehandlinger, rådgivning, myndighedsop-

Yderligere vil dele af midlerne blive øremærket til styrkelse af samarbejdet mellem det private erhvervsliv og de mange forskningsinstitutioner. Der skal således ifølge Danmarks Forskningspolitiske Råd satses på forskning og innovation for at skabe en langsigtet balance i velfærdssamfundets økonomi. ${ }^{7}$

\section{BEHOVET FOR PRACISERING AF DEN KUNSTMUSEALE FORSKNING}

Derfor finder jeg det væsentligt at fokusere på den humanistiske forskning og i særdeleshed den kunstmuseale forsknings muligheder for at positionere sig $\mathrm{i}$ forhold til regeringens udmeldinger.

I de humanistiske fagfora inden for Kulturministeriet har der siden begyndelsen af 1990 'erne været øget opmærksomhed på at indkredse, definere og kategorisere blandt andre den museale forsknings egenart, men det har vist sig at være vanskeligt at nå frem til enighed på feltet. Problemet synes at kredse om, hvilke dele af dem museale arbejde der reelt kan kategoriseres som forskning. Dette fremgår dels af den løbende diskussion, der har foregået siden 1990'erne i diverse forskningsudvalg nedsat under Kulturministeriet ${ }^{8}$, dels af et forskningsseminar, arrangeret af Kunsthistorisk Fagligt Råd under Kulturarvsstyrelsen i marts måned sidste år.

Iflg. Den danske museumslov er den museale forsknings omdrejningspunkt det enkelte museums indhold. Samlingerne er altså medvirkende til at afgrænse forskningsfeltet for museerne.

Museerne skal kort sagt opfylde de lovmæssige krav, der stilles dem, og udføre forsk- 
204 ningsarbejde, der er ajourført med aktuelle anvendelsesorienterede og samfundsrelevante emner, for at komme i betragtning til forskningsstøtte fra Videnskabsministeriet.

\section{DET MUSEALE FORSKNINGSBEGREB}

For at nå til bunds i forståelsen af, hvad der er på færde i det danske kulturministerium og videnskabsministerium, er det nødvendigt først at karakterisere, hvad det er man definerer som et "musealt forskningsbegreb" i den igangværende debat på området.

Det er min opfattelse, at debatten er delt i to lejre: de bevilligende myndigheder der ser det som nødvendigt, at museerne $\mathrm{i}$ deres forskning forholder sig til kravene om samfundsrelevans og anvendelsesorientering, og de museumsansatte der mener, at samfundet $\mathrm{i}$ sine forskningskrav bør tage højde for museernes særegne status på det forskningsmæssige område.

I den danske Museumslov, der umiddelbart skulle skabe rammerne for museumsforskning, behandles emnet i lovens to første paragraffer, hvor følgende kan læses:

\$1. Lovens formål er at fremme museernes virksomhed og samarbejde med henblik på at sikre Danmarks kultur- og naturarv samt adgang til viden om denne og dens samspil med verden omkring os.

Stk.2 Med mindre andet er fastsat finder lovens regler anvendelse på de statslige museer under Kulturministeriet og på de statsanerkendte museer, der modtager statstilskud efter loven.

\$2. Gennem indsamling, registrering, bevaring, forskning og formidling er det museernes opgave:

1) at virke for sikring af Danmarks kultur- og naturarv
2) at belyse kultur-, natur- og kunsthistorien

3) at udvikle samlinger og dokumentation inden for deres ansvarsområde

4) at gøre samlinger og dokumentation tilgængelig for offentligheden og

5) at stille samlinger og dokumentation til rådighed for forskning og udbrede kendskabet til forskningens resultater. ${ }^{9}$

[mine understregninger og kursiveringer]

I lovgivningen står det ikke direkte, hvad der i museumsarbejdet kan kategoriseres som forskning, og der arbejdes heller ikke med et specifikt defineret museumsforskningsbegreb. Alligevel kan der læses, at det umiddelbart er museernes samlinger og de museale genstande, der afgrænser det enkelte museums forskning. Som direkte reaktion på disse vage formuleringer i lovgivningen diskuteres det derfor indgående $\mathrm{i}$ fagkredse $\mathrm{i}$ dag, hvordan museumsforskning afgrænses, og hvad der definerer dette forskningsfelts empiriske fundament.

I forsøget på fra kulturministeriel side at udstikke nogle forskningsmæssige retningslinier fik først Kulturministeriets Rådgivende Forskningsudvalg i 199510 og senere Kulturministeriets Forskningsudvalg i september $1997^{11}$ til opgave at klarlægge feltet ved hjælp af nogle forskningskategorier. Disse blev formuleret på baggrund af OECD's gældende forskningsbegreber og er således en generel forskningsvejledning for alle typer kulturministerielle forskningsinstitutioner: arkiver, biblioteker og museer (under ét kaldt ABM- institutionerne eller De Kulturministerielle Sektorforskningsinstitutioner).

Den gældende kategorisering opererer med 2 overordnede forskningsbegreber, basisforskning og forsknings- og udviklingsarbejde. Disse to kategorier er inddelt i 5 underkategorier: under basisforskningen findes forskningsbe- 
greber som grundforskningen og den strategiske forskning, og under forsknings- og udviklingsarbejde findes begreberne anvendt forskning, udviklingsarbejde og reflekteret dataindsamling.

Væsentligt er det her at bemærke, at grænserne mellem grundforskning, strategisk forskning, anvendt forskning, udviklingsarbejde og reflekteret dataindsamling generelt er uklare, og at det ikke $i$ alle sammenhænge er muligt at skelne skarpt imellem dem. Af samme årsag er disse forskningskategorier udskældte i de museumsfaglige miljøer. Hvorfor vil fremgå senere i denne artikel.

\section{KAN MUSEAL FORSKNING OVERHOVEDET DEFINERES?}

På trods af at det dagligt må være en udfordring på de enkelte museer landet over at definere, hvad det egentlig er, man foretager sig, når man arbejder med sine genstande, synes debatten at være præget af politiske dagsordner, som kan inddeles $\mathrm{i}$ tre forskellige fora:

Det universitare forum: Repræsenteret af lektor, ph.d. ved Institut for Kultur og Medier på Danmarks Bibliotekshøjskole Hans Dam Christensens og hans artikel "Museumsforskning og forskningsformidling - betragtninger over kunstens vidensorganisering på udstillinger" i antologien "Ny Dansk Museologi" udgivet i 2005 (red. Ane Hejlskov Larsen \& Bruno Ingemann).

I denne artikel definerer Hans Dam Christensen den museale forskning som særlig i sin karakter grundet genstanden. Han mener dog ikke, på trods af erkendelsen af genstandens væsentlighed, at forskningsfeltet overordnet set bestemmes af det enkelte museums lovgivningsmæssigt anviste ansvarsområde (her menes de 5 søjler). Han ser det således som væ- sentligt, at de museale institutioner i fremtiden ser ud over deres hidtidige forskningstraditioner og i stigende grad forholder sig til nye præmisser som eksempelvis den museale forsknings anvendelighed og samfundsrelevans.

Det politiske forum: Repræsenteret af Kulturministeriets Forskningsudvalgs formand Kirsten Hastrups indlæg ved forskningsseminar på Thorvaldsens Museum 12. marts 2007 arrangeret af Kunsthistorisk Fagligt Råd under Kulturarvsstyrelsen.

Ved dette seminar gjorde Kirsten Hastrup sig til talsmand for et forskningsbegreb, der ikke er funderet i forestillingen om den genstandsbaserede forskning som en særlig museal forskningstype. Hendes forskningsdefinition er derimod forankret i tanken om et overordnet, humanistisk-generisk forskningsbegreb, og hun mener derfor, at den museale forskning bør betragtes i et generelt humanistisk lys og foreslår at inddrage såvel konkrete genstande som abstrakte teorier, der rækker ud over museernes fastlagte genstandsrammer, i forskningsprocessen.

Det teoretisk-museale forum: Repræsenteret af forskningschef på Statens Museums for Kunst Peter Nørgaard Larsens indlæg ved forskningsseminar på Thorvaldsens Museums 12. marts 2007 arrangeret af Kunsthistorisk Fagligt Råd under Kulturarvsstyrelsen.

Nørgaard Larsens forskningsbegreb er funderet i samlingen og dermed genstanden, hvor genstandsfeltet overordnet set bestemmes af museets ansvarsområde og museets egen forskningsstrategi. Han ser det som væsentligt for de museale institutioner, at det museumseksterne forskningsmiljø anerkender den fundamentale betydning af den forskning, der bedrives på kunstmuseale institutioner, og inddrager mangfoldigheden af kategorier og 
publikationsformer i vurderingen af det arbejde, der udføres på de forskellige institutioner.

For nemheds skyld har jeg ved hjælp af et skema forsøgt at kortlægge, hvilke forskningsmæssige traditioner de enkelte forskere indskriver sig i. Dette gøres, så min læser, uden at have de pågældende tekster præsent, er i stand til at følge argumentation undervejs. Desuden giver skemaet også et indblik i, hvorledes den museale forskningstradition betragtes ude- og indefra.

\section{DEN MUSEALE SAMLING SOM FORSKNINGSUDGANGSPUNKT}

Peter Nørgaard Larsen og Hans Dam Christensen opererer i deres tekster med næsten samme definition af den kunstmuseale forskning. Begge erkender de, at forskning af denne karakter fremstår unik og kan afgrænses med udgangspunkt i det enkelte museums kunstsamling. Imellem disse synspunkter står Hastrup, der sætter spørgsmålstegn ved, om

\begin{tabular}{|c|c|c|}
\hline Det universitcre forum & Det politiske forum & Det teoretisk- museale forum \\
\hline Hans Dam Christensen & Kirsten Hastrup & Peter Nørgaard Larsen \\
\hline $\begin{array}{l}\text { Den museale forsknings } \\
\text { grundelement } e r \text { genstanden } \\
\text { forstået som samlingen. }\end{array}$ & $\begin{array}{l}\text { Den museale forsknings } \\
\text { grundelement er ikke nødven- } \\
\text { digvis genstanden forstået som } \\
\text { samlingen. }\end{array}$ & $\begin{array}{l}\text { Den museale forsknings } \\
\text { grundelement } \text { er samlingen og } \\
\text { dermed genstanden. }\end{array}$ \\
\hline $\begin{array}{l}\text { Forskningsfeltet afgrænses } \\
\text { ikke overordnet set af museets } \\
\text { lovgivningsmessigt anviste } \\
\text { ansvarsområde. }\end{array}$ & $\begin{array}{l}\text { Forskningsfeltet bør betragtes } \\
\text { i et generelt overordnet huma- } \\
\text { nistisk lys og således inddrage } \\
\text { såvel konkrete genstande som } \\
\text { abstrakte teorier. }\end{array}$ & $\begin{array}{l}\text { Forskningsfeltet afgrænses } \\
\text { overordnet set af museets lov- } \\
\text { givningsmassigt anviste an- } \\
\text { svarsområde og det enkelte } \\
\text { museums ansvarsområde. }\end{array}$ \\
\hline $\begin{array}{l}\text { Fremtidige betragtninger: } \\
\text { Væsentligheden i at de musea- } \\
\text { le institutioner ud over deres } \\
\text { hidtidige forskningstraditioner } \\
\text { også forholder sig til nye teo- } \\
\text { retiske præmisser som eksem- } \\
\text { pelvis den museale forsknings } \\
\text { anvendelighed og samfunds- } \\
\text { relevans. }\end{array}$ & $\begin{array}{l}\text { Fremtidige betragtninger: } \\
\text { Væsentligheden i at den mu- } \\
\text { seale forskning i fremtiden ser } \\
\text { sig forankret i tanken om et } \\
\text { overordnet humanistisk-generisk } \\
\text { forskningsbegreb og at den } \\
\text { fremtidige forskning rekker ud } \\
\text { over museernes fastlagte gen- } \\
\text { standsrammer. }\end{array}$ & $\begin{array}{l}\text { Fremtidige betragtninger: } \\
\text { Væesentligheden i at det mu- } \\
\text { seumseksterne forskningsmiljø } \\
\text { anerkender betydningen af den } \\
\text { kunstmuseale forskning og } \\
\text { inddrager mangfoldigheden } \\
\text { af kategorier og publikations- } \\
\text { former } i \text { vurderingen af det } \\
\text { arbejde, der udføres pa de } \\
\text { forskellige institutioner. }\end{array}$ \\
\hline
\end{tabular}


den museale genstand reelt kan betragtes som forskningsfelt i sig selv. Hun mener, at et sådant udgangspunkt får den museale genstand til at virke hæmmende og afgrænsende for det enkelte forskningsprojekt frem for inspirerende. Umiddelbart synes jeg at kunne se udmærkede perspektiver i Hastrups betragtninger. Alligevel mener jeg ikke, at det er en mulighed for museerne at se bort fra deres genstande. Dette bygger jeg på følgende betragtninger: Skal det museale forskningsfelt udvides til at række ud over genstanden, er der to muligheder. Enten forøges den forskningsmæssige arbejdsbyrde på museerne, fordi forskning ud over samlingernes grænser kommer oven i den af lovgivningen påkrævede forskning, eller også er det nødvendigt at reformulere lovgivningen på helt basale områder, som i sidste ende vil kunne bringe den kunstmuseale kulturarv i fare, da museernes lovgivningsmæssigt afgrænsede ansvarsområder vil blive flydende og således mere udefinerbare, end de ses i dag.

Selvom Peter Nørgaard Larsen og Hans Dam Christensen begge definerer den museale forskning som en forskningstype, der tager udgangspunkt i det enkelte museums samlinger, ser de grundlæggende meget forskelligt på, hvad der i musealt regi kan defineres som forskning.

Peter Nørgaard Larsen mener, at indsamling, registrering, bevaring og formidling alle indgår som dele af den museale forskning. Hermed mener han grundlæggende, at de fleste af de arbejdsopgaver, en museumsinspektør varetager, til en vis grad alle rummer et element af forskning og derfor ikke kan varetages uden at den kunsthistoriske forskningsfaglighed er på plads. Ydermere fastslår Nørgaard Larsen, at i den optik behøver en ophængning ikke nødvendigvis at være et resultat af en langvarig forskningsproces, ophæng- ningen kan godt i sig selv fungere som forskning, da han mener, forskning kan baseres på udelukkende visuelt- æstetiske principper. Her mener Hans Dam Christensen det diametralt modsatte og pointerer, at udstillinger, der ikke har deres fundament i forskning, efterlader de udstillede værker afhistoriserede og fjernt fra deres oprindelige analytiske kontekst. Funderes en udstilling alligevel i udelukkende visuelt-æstetiske principper, overlades værkfortolkningen og således også værkforståelsen til publikum, uanset dettes forudsætninger. Samme holdning, som Hans Dam Christensen giver udtryk for, er at spore hos Kirsten Hastrup, der giver til kende, at det for hende virker usammenhængende, hvis en kunsthistoriker blot udpeger et billede og lader motivets æstetiske egenart tale for sig selv. For hende bør kunsthistorikeren opstille nogle retningslinier for beskueren, så der er noget for museumsgæsten at se efter på billedfladen.

Det er således kun den museumsansatte kunsthistoriker, der mener, at en udstilling, der er baseret på visuelt - æstetiske principper, kan ses som reelt forskningsprojekt. At Peter Nørgaard Larsen har netop den holdning kan skyldes, at det for ham, som fagligt velfunderet kunsthistoriker, kan være svært at opleve et kunstværk afhistoriseret og uden for dets oprindelige analytiske kontekst. Når der eksempelvis på Statens Museum for Kunst arbejdes med denne type udstillinger, og de fra museets side ses som forskningsprojekter, skyldes det efter min mening en overvurdering fra museets side af deres gæsters faglige forkundskaber. For det virker som om, man fra museets side forudsætter et minimumskendskab til kunsthistorien, der på denne måde er med til at skabe det faglige fundament, der gør det muligt for gæsterne selv at forholde sig kritisk-analy- 
208 tisk til værkerne, også selvom de optræder uden for deres oprindelige kontekst.

Det er dog min vurdering, at det under alle omstændigheder vil være givtigt at eksperimentere med ophængninger på tværs af ismer og stilarter, ellers stivner museerne i kronologiske og retrospektive udstillinger, der ikke bevæger sig ud over dokumentation af kunstneriske og historiske udviklingslinier. Jeg oplever da heller ikke, at hverken Dam Christensen eller Hastrup forkaster de eksperimenterende udstillinger - slet ikke - begge finder de det væsentligt, at en udstilling, hvis ophængning eksempelvis naturligt rejser en mængde analytiske og historiske spørgsmål, også er i stand til at besvare dem. Og de mener derfor begge, at en udstilling bør have et vist forskningsfundament, der kan fungere som hjælpende hånd for publikum og lede disse vellykket gennem udstillingen.

\section{DET FREMTIDIGE FORSKNINGSARBEJDE}

I et fremtidigt perspektiv adskiller Hastrups og Dam Christensens holdninger sig igen ikke væsentligt fra hinanden. Begge mener de, at museerne må se ud over hidtidige forskningstraditioner og tilpasse deres fremtidige forskningsarbejde, så de i højere grad kan stå mål med de krav, der stilles til forskning om anvendelsesorientering og samfundsrelevans.

Genstandsproblematikken er i lyset af ovenstående indlysende, at netop en genstandsafgrænsning eller genstandsdefinition er yderst påkrævet i en eventuel fremtidig museal forskningsdefinition.

De tre teoretikere bekender sig til tre forskellige museale forskningsopfattelser, der alle til en vis grad tager udgangspunkt $i$, hvor de befinder sig $i$ forhold til den museale forskning. Antropologen Hastrup har svært ved at se den (kunst)museale forskning som særlig i sin karakter, universitetsforskeren Dam Christensen ser ikke den museale forskning som tilstrækkeligt teoretisk i sin karakter, og den museale forskningschef Peter Nørgaard Larsen forsvarer det store stykke arbejde, der foregår på museerne og finder det problematisk, at kravene ustandseligt ændrer sig, og at arbejdet ustandseligt angribes udefra.

De gældende forskningsdefinitioner, der blandt andre af Peter Nørgaard Larsen er udskældte for dels at tage udgangspunkt i den naturvidenskabelige verden, dels ikke at tage hensyn til museumsforskningens vigtige genstands- og kulturarvsforpligtigelser og for endelig at virke hierarkiserende i deres forskningstypologi, synes uegnede $\mathrm{i}$ forsøget på at indkredse det museale forskningsbegreb.

\section{GLOBALISERINGSPULJEN}

I Peter Nørgaard Larsens kritik af de gældende forskningsbegreber er det væsentligt at fremhæve, at Kirsten Hastrup ved seminaret om kunstmuseernes forskning den 12. marts 2007 fastslog, at Kulturministeriets siddende Forskningsudvalg, for hvilket hun er formand, ikke opererer med en hierarkisering eller en gradbøjning af de gældende forskningsbegreber. Bedømmelsen af bevillingsansøgninger til f.eks. museal forskning foretages iflg. Hastrup af Kulturministeriets Forskningsudvalg, hvor 9 af de 7 medlemmer kommer fra Kulturministeriets institutioner. ${ }^{12}$ Det største problem i denne bevillingsproces er iflg. Hastrup ikke, om et givent projekt har grundforskningsstatus eller snarere har karakter af reflekteret dataindsamling, men at der fra museernes side sjældent redegøres særligt indgående for den gældende viden på det område, der søges forskningsmidler til. Hastrup påpeger, at dette 
kommer til at betyde, at det som udgangspunkt er vanskeligt for Forskningsudvalget at bedømme, hvad der kan karakteriseres som ny viden på området og dermed også være støtteberettiget

På trods af Hastrups afklaring af, at der ikke umiddelbart fra de bevilligende myndigheder hierarkiseres, når der uddeles bevillinger til museale forskningsprojekter, finder jeg det alligevel nødvendigt, som klarlagt hos Dam Christensen $^{13}$, at museerne forholder sig til kravene om samfundsrelevant og anvendelsesorienteret forskning. For selvom Hastrup ikke umiddelbart fremhæver dette som væsentligt, kan det spores indirekte $\mathrm{i}$ formuleringen:

[problemet er at der] fra museernes side sjældent er redegjort særligt indgående for den gældende viden på det område, der søges forskningsmidler til $[\ldots]^{14}$

Her bliver spørgsmålet: Er det projekt, der søges bevillinger til, reelt relevant, eller er det allerede et emne, der til en vis grad er gennemarbejdet? Vil det nye forskningsprojekt fremstå som nyt, selvstændigt projekt eller blot som tillægsbetragtninger til et allerede udforsket emne?

Det nyeste tiltag i forskningsbedømmelsesog væsentlighedsdebatten er det præsenterede pointsystem, der naturligt nok også er udskældt af Peter Nørgaard Larsen for ligesom forskningsdefinitionerne ikke at tage højde for den museale forsknings egenart. Systemet blev udviklet, da der fra Videnskabsministeriet ${ }^{15}$ blev bevilliget ekstra penge til forskning, bl.a. via den såkaldte "Globaliseringspulje", hvis formål er:

[at] medvirke til at gøre Danmark til et førende vækst-, videns- og iværksættersamfund [...] På forsknings- om-rådet afsættes en stigende udgiftsprofil med henblik på at efterleve målsætningen om at øge de offentlige forskningsbevillinger til $1 \%$ af bruttonationalproduktet frem mod 2010 [...] Forskningsmidlerne afsættes bl.a. til basisbevillinger, opbygning af forskningskapacitet, en styrkelse af den fri forskning og den strategiske forskning samt samarbejde med private om forskning og udvikling. ${ }^{16}$

Ministeriet ønskede i den forbindelse et vurderingsværktøj, og pointsystemet blev her udviklet $\mathrm{i}$ et forsøg på at fastslå forskningens kvalitet og relevans:

Forskningspolitiske vurderinger bør foretages på et gennemskueligt og veldokumenteret grundlag. Det er derfor nødvendigt at have et fælles værktøj til synliggørelse af forskningens kvalitet og relevans. Danmarks forskningspolitiske råd har gennem arbejdet med identificering af kernefelter i dansk forskning udviklet og afprøvet et værktøj til vurdering af dansk forsknings kvalitet og relevans ved hjælp af internationalt sammenlignelige kriterier. ${ }^{17}$

\section{Museerne MÅLEs og VEJES}

Kvalitetsvurderinger udsættes alle Kulturministeriets institutioner for store som små og umiddelbart synes det måske ikke problematisk for store institutioner som Statens $\mathrm{Mu}$ seum for Kunst eller Nationalmuseet at se sig underlagt et vurderingssystem af ovenstående karakter. Men på de mindre museer kan de nye regler blive svære at forholde sig til, da systemet tilsyneladende skal udgøre museernes økonomiske forskningsfundament. Nogle institutioner er simpelthen så små, at de kun har et halvt eller et kvart forskerværk, og på baggrund heraf bliver det nødvendigt, når det omtalte pointsystem til forskningsmåling fra 2009 træder $\mathrm{i} \mathrm{kraft}{ }^{18}$, at denne type institutio- 
210 ner fra starten forholder sig til systemet, og allerede nu målretter deres bevillingsansøgninger efter det. Sker dette ikke, kunne man frygte, at denne type forskningsinstitutioner risikerer at ende i en, ond cirkel hvor deres forskning, på grund af $\mathrm{i}$ forvejen manglende tid og midler, ikke bliver af en kvalitet, der giver tilstrækkeligt med point, hvilket påvirker finansieringen, der så igen kommer til udtryk i resultater præget af manglende midler og tid. Sker dette, mister disse institutionstyper helt muligheden for at ansøge om de vigtige forskningsmidler og kobles således også af systemet som reelle forskningsinstitutioner.

I yderste konsekvens vil det betyde, at pointsystemet kvæler de mindre danske museers bidrag til det generelle forskningslandskab, hvilket formentlig kommer til at berøre især forskningen i de særligt danske felter, da netop disse i bredere europæisk optik synes mindre væsentlige.

En anden oplagt fare ved et pointsystem bliver, at basisforskningen kan få et "knæk" på trods af, at puljer som globaliseringspuljen er skabt til bl.a. at "styrke den fri forskning", en udvikling, Hans Dam Christensen så allerede et år før, pointsystemet blev præsenteret.

\section{FORSKNINGSMÅLING}

Med de ovennævnte problemstillinger in mente bør der i allernærmeste fremtid fastlægges nogle forskningsdefinitioner, der matcher de museale institutioners forskningsform, og som kan fremsættes som modforslag til de nu opstillede vurderingskriterier. I definitionerne vil det være væsentligt ikke blot at forholde sig til den museale genstand, men også en gang for alle at få fastslået, at den museale forskning ikke kan begrenses til kun at omfatte publikatio- ner, men i høj grad også omfatter udstillingsvirksomheden.

Man kan dog ikke påstå, at museerne ikke har modtaget klare hints om den forestående udvikling, for pointsystemer til at måle forskningskvalitet er ikke noget nyt. Flere lande bruger allerede noget sådant og tæller ikke bare sammen, hvor meget forskerne publicerer, men også hvor mange gange de bliver citeret, og i hvilke tidsskrifter de publicerer. Jo mere prestigefyldte tidsskrifter deres artikler optræder i, jo flere point får forskerne. Når Videnskabsministeriet således begrunder den eventuelle indførelse med, at det er den vej, den internationale udvikling går, bekræfter det desværre min påstand om, at de museale institutioner tilsyneladende har siddet dette overhørig og opretholdt den holdning. Det er tankevækkende, at gennem de seneste 10 år har det været muligt at iagttage en langsom forandring i tilgangen til det museale forskningsbegreb, og den museale verden i det hele taget, først med lanceringen af de nye forskningsdefinitioner i slutningen af 90'erne til præsentationen af det nye pointsystem. Undervejs i denne periode er museerne blevet præsenteret for nye tiltag som kvalitetsvurderinger, resultatkontrakter, eksterne evalueringer og meget mere, alt sammen med henblik på fra ministeriel side at klarlægge det enkelte museums relevans og samfundsberettigelse. De mange nye tiltag har selvfølgelig været debatskabende, men debatterne har fortrinsvis drejet sig om de enkelte tiltag - ikke om den generelle udvikling og den stigende fokus på samfundsrelevans.

Den forskningsmæssige udvikling inden for museernes mure synes bl.a. i lyset af Peter Nørgaard Larsens udtalelser generelt at have været overvejende upåvirket af samfundsudviklingen. I mine øjne er det derfor ikke lyk- 
kedes at få fasttømret, hverken i politikernes eller i befolkningens bevidsthed, at den humanistiske forskning bidrager til samfundet, måske ikke med tiltag, der umiddelbart kan måles som økonomisk vækst, men med tiltag, der kan måles i noget lige så værdifuldt, nemlig velfærd og samfundsmæssigt overskud. En strategisk fejlvurdering fra det museale fagmiljøs side, der desværre i fremtiden kunne komme til at koste museerne dyrt i forskningsmidler og dermed også på deres forskningsoverskud og forskningstid.

Kvalitetsvurderingskriterierne er blevet reduceret til måling af publikationer og internationalt samarbejde. Og relevans er til en vis grad blevet til økonomisk relevans - eller samfundsrelevans, og det kan her virke urimeligt, at det omfattende udstillingskatalog ikke pointsættes efter arbejdsindsats, men at tendensen går i retning af, at monografien og antologien efterprøves som kondenseret viden i fagtidsskrifter.

Da det på nuværende tidspunkt efter al sandsynlighed er umuligt for de museale institutioner at standse udviklingen, mener jeg, de enkelte humanistiske forskningsområder i fremtiden må forsøge at forholde sig konstruktivt til udviklingen og fastlægge nye forskningsmæssige idealer med fokus på såvel forskning på internationalt niveau som forskning, der er samfundsrelevant.

\section{UBRUGELIGT MÅLINGSSYSTEM}

I lyset af manglen på definitioner af den museale forskningstypes særlige karakter og manglende argumenter $\mathrm{i}$ debatten om denne forsknings samfundsrelevans og anvendelsesorientering fremstår, Peter Nørgaard Larsens fremsatte argument på seminaret den 12 . marts sidste år, som det tilbageværende bedste synspunkt i debatten om det nye pointsystem, de kunstmuseale institutioner kan fremsætte. Han fandt, at det præsenterede pointsystem ikke lader sig anvende i forhold til den humanistiske forskning, men måske nok på den naturvidenskabelige forskning. Det viser sig imidlertid, at heller ikke alle forskere fra den naturvidenskabelige verden finder pointsystemet brugbart. I et af de mest prestigefyldte tidsskrifter, det amerikanske "Nature", fremsætter professorerne Andrew D. Jackson og Benny Lautrup fra Niels Bohr Instituttet samme synspunkt. I artiklen "Measures for measures", udgivet den 21. december 2006, undersøgte de to forskere de metoder, der ligger til grund for den præsenterede kvalitetsmåling af forskningen. De konkluderer, at de pointsystemer og algoritmer, man bruger til at sammenligne forskernes produktion, ikke giver megen mening, og at man lige så godt kunne lave en rangliste over forskere ud fra deres forbogstaver som via optælling af videnskabelige artikler. I artiklen "Ranking: Forskning på metermål" i den danske avis Information fra den 9. februar 2007 udtaler Benny Lautrup følgende:

En af vores konklusioner er at selv med de bedste metoder, så giver det ikke megen sikkerhed i vurderingen. Selvfølgelig er det for eksempel godt at få en artikel i Nature fordi det er svært, men det siger i princippet ikke så meget om artiklens eller forskningens kvalitet [...] Når man ikke kan finde ud af at måle det man vil måle, så måler man det man kan, men det har intet andet formål end at gøre det nemt for administrationen at fordele forskningsmidler og kontrollere om forskerne nu også laver nok. På den måde er man jo helt fritaget for ansvar men en sådan algoritmisering af forskningen kan skabe en forfærdig masse problemer [...] Biologien og sundhedsvidenskaben sprøjter jo forskningsartikler ud mens der normalt er læng- 
212 ere tid mellem artiklerne for en matematiker. Fysikken ligger midt imellem disse yderpunkter. ${ }^{19}$

I artiklen anbefaler Benny Lautrup desuden, at man udøver kvalitetssikring på den "gammeldags maner" ved rent faktisk at læse artiklerne og bedømme dem ud fra deres indhold.

Interessant er det altså, at topfolk fra naturvidenskaben som Benny Lautrup påviser, at systemet umiddelbaret synes udviklet som et redskab, der gør ikke-fagfolk i stand til at vurdere forskningen på helt generelle præmisser, set $i$ lyset af, at han selv har over 200 publikationer bag sig og efter disse nye regler ville kunne score masser af point.

Opsummeres der på ovenstående, mener jeg at kunne fastslå, at problematikken ligger $i$, at man fra ministeriel side, uden egentlig at forholde sig til, om den internationale udvikling på forskningsmålings- og vurderingsområdet overhovedet er holdbar, ønsker at følge denne. Desuden synes det mindre heldigt, at man principielt ønsker at generalisere al form for forskning, humanistisk som naturvidenskabelig, til én stor ikke nærmere defineret, men målelig størrelse.

Jeg oplever det som mærkværdigt, at forskning bliver kategoriseret i en bedre klasse, hvis den udkommer på engelsk, tysk eller fransk uden hensyntagen til indholdet. Jf. Benny Lautrups udtalelse er det derfor vigtigt at rette fokus mod den gruppe, der i fremtiden kommer til at sidde med forskningsevalueringerne. Det er meget vigtigt, at der her findes kompetente fagfolk, der kan spotte forskningsmæssige nybrud og derved ikke kun fordeler pengene efter højeste score, men også efter forskningsmæssigt indhold og kvalitet.

Desuden er det min holdning, at kvalificeret bedømmelse og vurdering af forskningsresultater i fremtiden bør tage udgangspunkt i det allerede eksisterende evalueringssystem, men tillige baseres på dialog- og kontraktsystemer mellem den enkelte forskningsinstitution og den ministerielle ledelse. Ministeriet vil dermed løbende, både internt og eksternt, kunne evaluere på forskningens kvalitet frem for dens kvantitet, som det nye pointsystem indirekte synes at lægge op til.

Som billedet ser ud nu, flyder forskningsbegreberne, og det samme gør de debatter, der følger dem. Dette gør de museale og dermed også de kunstmuseale fremtidsudsigter usikre og dystre. Hastrup taler om et decideret humanistisk samfundsproblem (Hastrup 1999: Forord), og som billedet tegner sig netop nu, ser det desværre ud som om, museerne til dels selv er skyld i denne udvikling, da der ikke i tide er blevet reageret.

\section{FORSKNINGSDEBATTEN SET LIDT FRA OVEN}

Samfundsudviklingen peger i retning af forskningsmåling, hvad enten det drejer sig om kvaliteten af forskningen, mængden af forskningen eller forskningens anvendelsesorientering. Målingen og vægtningen af det forskningsmæssige arbejde er kommet for at blive.

Af samme årsag anser jeg det for nødvendigt, at såvel museerne som de forskningsvurderende instanser udarbejder målingskriterier, der svarer til den museale forsknings karakter, og dette skrives velvidende, at definitionen af den kunstmuseale forskning endnu ikke er tilendebragt.

Kirsten Hastrup præsenterede undervejs i sit indlæg den 12. marts 2007 syv kvalitetsmål, der som minimum i hendes øjne bør opfyldes, for at forskningens kvalitet kan siges at være tilstrækkelig. Disse mål er ikke rettet specifikt mod den museale eller den kunstmusea- 
le forskning, men i højere grad mod den humanistiske forskning generelt. Hastrups mål finder jeg væsentlige i mit forsøg på at klarlægge, hvad der kan virke med til at skabe et vellykket fundament for kvalitetsvurdering af humanistisk forskning. Ydermere ser jeg hendes mål som et tungtvejende argument i debatten om, hvorvidt det er hensigtsmæssigt at foretage generelle forskningsmålinger af alle typer af humanistisk forskning via vurderinger af publikationskvalitet og -relevans.

Hastrup finder det væsentligt, at den humanistiske forskning fremstår robust i sin karakter og kan holde vand ved efterprøvning. Der skal være konsistens mellem materiale og analytisk objekt, og der skal være overensstemmelse mellem det, der ender med at være et empirisk udsnit af verden, og det analytiske objekt. Ydermere er det væsentligt med såvel metodegennemsigtighed som dialog mellem emne og udvalgt litteratur. Sidst og ikke mindst vigtigt finder Hastrup det essentielt, at forskeren forholder sig til gældende viden på feltet og demonstrerer sammenhæng i argumentationen, når den nye viden deles og udsættes for afprøvning. Af sidstnævnte grund ser Hastrup nødvendigheden $i$ at publicere. For det er gennem publikationen den nye videns robusthed afprøves, og derfor bliver dette parameter, publikationen, $\mathrm{i}$ hendes øjne et af de vigtigste kvalitetsmål.

Peter Nørgaard Larsen fremsatte ligeledes den 12. marts sidste år en række målingsforslag. Hans udgangspunkt optræder dog ikke nær så generelt i sin karakter som Hastrups, og af samme årsag finder han det yderst problematisk, at der udarbejdes forskningsmålingskriterier, der ikke tager højde for den museale forsknings særlige karakter. Han mener umiddelbart, at den museale forskningsmåling foretaget udelukkende via publikations- måling er utilstrækkelig, og påpeger, at det så213 ledes for kunstmuseernes vedkommende må sikres, at de bevilligende myndigheder i udarbejdelsen af fremtidige målingskriterier respekterer mangfoldigheden af museale publikationer og tager hensyn til de forskellige museale institutioners særlige kulturarvsforpligtigelser, der ofte er af helt særlig national karakter.

I forlængelse af både Kirsten Hastrups og Peter Nørgaard Larsens overvejelser finder jeg det af stor betydning at fokus rettes mod den gruppe, der i fremtiden kommer til at sidde med forskningsevalueringerne. Her bør findes kompetente fagfolk fra museernes verden, der kan spotte væsentlige nye forskningsmæssige opdagelser. Desuden anser jeg det for centralt, at en fremtidig bedømmelse og vurdering af de museale forskningsresultater tager udgangspunkt i en udbygning af det allerede eksisterende evalueringssystem, så det i fremtiden vil indbefatte en klar definition af den museale forsknings egenart. Således kan kvalitetsvurderingerne $\mathrm{i}$ fremtiden blive baseret på dialog- og kontraktsystemer mellem den enkelte museale forskningsinstitution og den ministerielle ledelse, og museerne vil således ikke på samme måde som nu føle, at deres forskningsarbejde bliver fejlanbragt i naturvidenskabelige forskningskategorier og dermed ligestillet med forskningstyper, der umiddelbart ligger museerne fjernt.

\section{NOTER}

1. Aftale om fremtidens velstand og velfard og investeringer i fremtiden, juni 2006 indgået mellem regeringen (V og K) socialdemokraterne, Dansk Folkeparti samt Det Radikale Venstre, p. 85 ff. 
2. Samspil-nye veje mellem forskning og erhverv, september 2003, p. 6-7.

3. Aftale om fremtidens velstand og velfard og investeringer i fremtiden, juni 2006 p. 9-10+17 - 18 .

4. Et verktøj til vurdering afforskningens kvalitet og relevans. Danmarks Forskningspolitiske Råd, juni 2006.

5. Ibid. $\mathrm{p} 6$.

6. Ibid. $\mathrm{p} 6$.

7. Aftale om fremtidens velstand og velfard og investeringer i fremtiden, juni 2006 p. 9-10.

8. Se bl.a. handlingsplaner fra Kulturministeriets Forskningsudvalg 1994-200 + 2001-2004 samt Beretning fra Kulturministeriets Rådgivende Forskningsudvalg 1993-1995.

9. Museumslov. Lov nr. 473 af 7 . juni 2001.

10. Kulturministeriets Rådgivende Forskningsudvalg, beretning 1993 - 1995.

11. Kulturens Forskning 1994-2000, handlingsplan fra Kulturministeriets Forskningsudvalg.

12. Det siddende udvalg med Kirsten Hastrup i spidsen kan ses på følgende hjemmeside: http://www.kum.dk/sw2954.asp

13. Og det på trods af at Hans Dam Christensen ikke på det tidspunkt, han udgav sin artikel, kendte til den enorme udvikling, forskningsvurderingen frem til skrivende stund har gennemgået.

14. Anette Sevaldensens referat fra forskningsseminaret på Thorvaldsens museum, marts 2007, p. 10.

15. Bevillingen kom på foranledning af de satsningsområder, som blev defineret af Velfærdskommissionen bl.a. i: Aftale om fremtidens velstand og velfard og investeringer i fremtiden, juni 2006, s. $85 \mathrm{ff}$.

16. Aftale om udmontning af globaliseringspuljen, s. 7-8.

17. Danmarks Forskningspolitiske Råd: Et verktøj til vurdering afforskningens kvalitet og relevans, juni 2006. s. 3 .
18. "Naturvidenskabens måling af forskning er problematisk". Information, 10/12-07.

19. Ranking: Forskning på metermål. Information 9. februar 2007.

\section{LITTERATUR}

Hans Dam Christensen: "Museumsforskning og forskningsformidling- Betragtninger over kunstens vidensorganisering på udstillinger”. In: Ane Hejlskov Larsen \& Bruno Ingemann red. $N y$ Dansk Museologi p. 263-277, Århus 2005.

Kirsten Hastrups indlæg ved forskningsseminar på Thorvaldsens Museum 12. marts 2007 arrangeret af Kunsthistorisk Fagligt Råd under Kulturarvsstyrelsen.

Hastrup, Kirsten, Viljen til viden, København 1999. Peter Nørgaard Larsens indlæg ved forskningsseminar på Thorvaldsens Museum 12. marts 2007 arrangeret af Kunsthistorisk Fagligt Råd under Kulturarvsstyrelsen.

Anette Sevaldsen: Referat af seminar om kunstmuseernes forskning på Thorvaldsens Museum, 12. marts 2007, kl. 10-16.30. På hjemmesiden: http://www.kulturarv.dk/forvaltning/udvalg/faglige_raad/kunsthistorie/referater/2007-03-27_seminarreferat.pdf

Beretning 1993-1995. Kulturministeriets Rådgivende Forskningsudvalg, 1995.

Kulturens forskning 1994-2000. En handlingsplan fra Kulturministeriets Forskningsudvalg, 1997.

Danmarks kreative potentiale. Kultur- og erhvervspolitisk redegørelse, 2002.

Kultur Profilen - Kulturens forskning 2001-2004. En handlingsplan fra Kulturministeriets Forskningsudvalg, 2001.

Den danske Museumslov: Lov nr. 473 af 7. juni 2001. Samspil - Nye veje mellem forskning og erhverv.

Baggrundsrapport fra Videnskabsministeriet, 
2003.

Et varktøj til vurdering af forskningens kvalitet og relevans. Danmarks Forskningspolitiske Råd, juni 2006.

Aftale om udmontning af globaliseringspuljen. Finansministeriet, 2006 http://www.fm.dk/db/filarkiv/15938/Globaliseringspuljen_samlet_aftale.pd f.

Ranking: Forskning på metermål. In: Information 9. februar 2007.

Naturvidenskabens måling af forskning er problematisk. In: Information 10. december 2007 http://www.information.dk/151589.

*Mag.art. Signe Margrethe Eberhardt Sørensen

Address: Mariedalsvej 16

8220 Brabrand

Mobil: 41900259

E-mail: S_jensen79@hotmail.com 